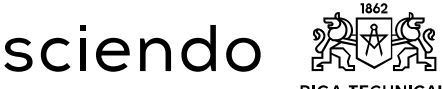 \\ RIGA TECHNICAL
UNIVERSITY
}

\section{PUBLIC PROCUREMENT OF INNOVATION: SELECTION OF THE SUSTAINABLE ALTERNATIVE}

\author{
Viktorija BABICA $^{1}$, Deniss SCEULOVS ${ }^{2}$ \\ ${ }^{1,2}$ Riga Technical University, Riga, Latvia \\ Corresponding author e-mail: deniss.sceulovs@rtu.lv
}

\begin{abstract}
The European Union has been highly emphasising the role of public procurement for innovation as a policy instrument that can be used to stimulate sustainable development. This development reflects and responds to improvements in social welfare, growth of entrepreneurship and of national competitive advantage. In the process of selection, the awarding tender public procurement institutions lack an overall approach for choosing the most advantageous and sustainable innovation alternative. To contribute purchasing of innovative solutions, the present paper elaborates a framework of innovation measurement and quality evaluation. Thus, it makes possible to assess proposals from different aspects and to choose the most valuable offer notwithstanding the lowest price criteria.

The paper studies the concept of public procurement, its pitfalls and prospects, dimensions of innovation definition and innovation added value assessment. The authors conducted expert interviews, which were analysed using an AHP method in order to set the most appropriate evaluation criteria indicator. The authors also designed the framework for assessing the quantitative and qualitative value of innovation proposals. The proposed approach is based on the analysis of innovation quality, added value, its potential impact and the sustainability of changes it produces.
\end{abstract}

Keywords: Best tender, innovation, innovation evaluation, public procurement, public procurement of innovation, sustainable innovation, quality

JEL Classification: Q31, Q39.

\section{INTRODUCTION}

Sustainable development, which premises social welfare, growth of entrepreneurship and international competitiveness, is the key objective of the European Union. In the 20th century, innovation is described as the creative destruction or industrial mutation process that constantly changes the existing economic structure, destroying the old and creating the new. Nowadays, innovation is seen as an essential part of business and a key factor of its success. Public authorities implement public procurement procedures to promote efficient, sustainable and inclusive growth by ensuring the most efficient use of public funds.

Procurement of innovation is one of the most effective policy tools for knowledge-based economic development; it provides efficient, smart and economical consumption of resources, develops a green economy, and promotes decoupling. 
The outcome of the procurement process depends on the award criteria and the qualifications of the stakeholders involved. Most procurement procedures are still valued using the lowest price criterion, destroying both innovation and competition among suppliers. There is no single sustainable model for the evaluation of proposals. The main pitfalls of public procurement of innovation are the formulation of tenders, conservatism of society, avoidance of risk and change, evaluation and selection of the best alternative.

\section{THEORETICAL ASPECTS}

\subsection{Public Procurement (PP)}

Public procurement of innovation (PPI) has become the matter of focus among EU governmental bodies. One basic justification for making public procurers more prone to innovation is that public procurement annually represents up to $16 \%$ of EU gross domestic product (GDP), a purchasing power, which if directed wisely could significantly contribute to the EU sustainability and welfare through innovation, technical transfer and knowledge share (European Commission, 2019).

Public procurement comprises and operates tenets of neoliberalism and neoclassical economy (Cox, 1995) - creation of a free market, evolving the need to continually improve international competitiveness, guided by principle of transparency and non-discrimination. Although the profit maximisation is not a priority for most public buyers (Kunzlik, 2013), their political interests mainly relate to cost-effectiveness of public spending (Lember, 2014). Hence, it is essential to define the concept of the most advantageous tender.

Public entities can embody the role of an intermediary or a public money holder, who through public procurement, would implicitly be returning to the public its assets, which were paid in taxes, by supporting entrepreneurship, raising the level of prosperity, improving the country's competitiveness and promoting the transfer of international knowledge. Public procurement can contribute to the ecoeconomic decoupling effect (Hennicke, 2014), support sustainable economic development and favour to inclusion of equal society.

\subsection{Innovation, Invention and Technology Transfer}

To meet the needs of society with sustainable and smart solutions, it is necessary to develop an administrative culture in the country that by default supports the innovation policy.

Innovation used to be described as creative destruction or a process of industrial mutation (Schumpeter, 1942) that continually changes the existing, destroying the old and creating a new one. Development of new combinations of changes (Schumpeter, 1934) may emerge in new products, processes, new manufacturing methods, new markets and supply chains, new organisational methods and others novelties, which proffers the most favourable alternative to the one existing.

Deliberately creating a long-lasting and repetitive value or utility is associated with a certain company, educational institution, market or industry, municipality, state, but is not consistently ought to be global (Ahuja, 2001). According to 
Hamberg (1959), the added value of product and process innovation can be represented in the production function, but not all the factors influencing it could be reflected.

The paper examines the concept of innovation, which states that innovation is a process of a new or substantially improved product, idea, method or business process being implemented or commercialised in the market or organisation, creating a new value for the consumer, competitive advantage and improving the welfare of society. The term defines an innovating activity, as well as an innovative result of it (Fig. 1).

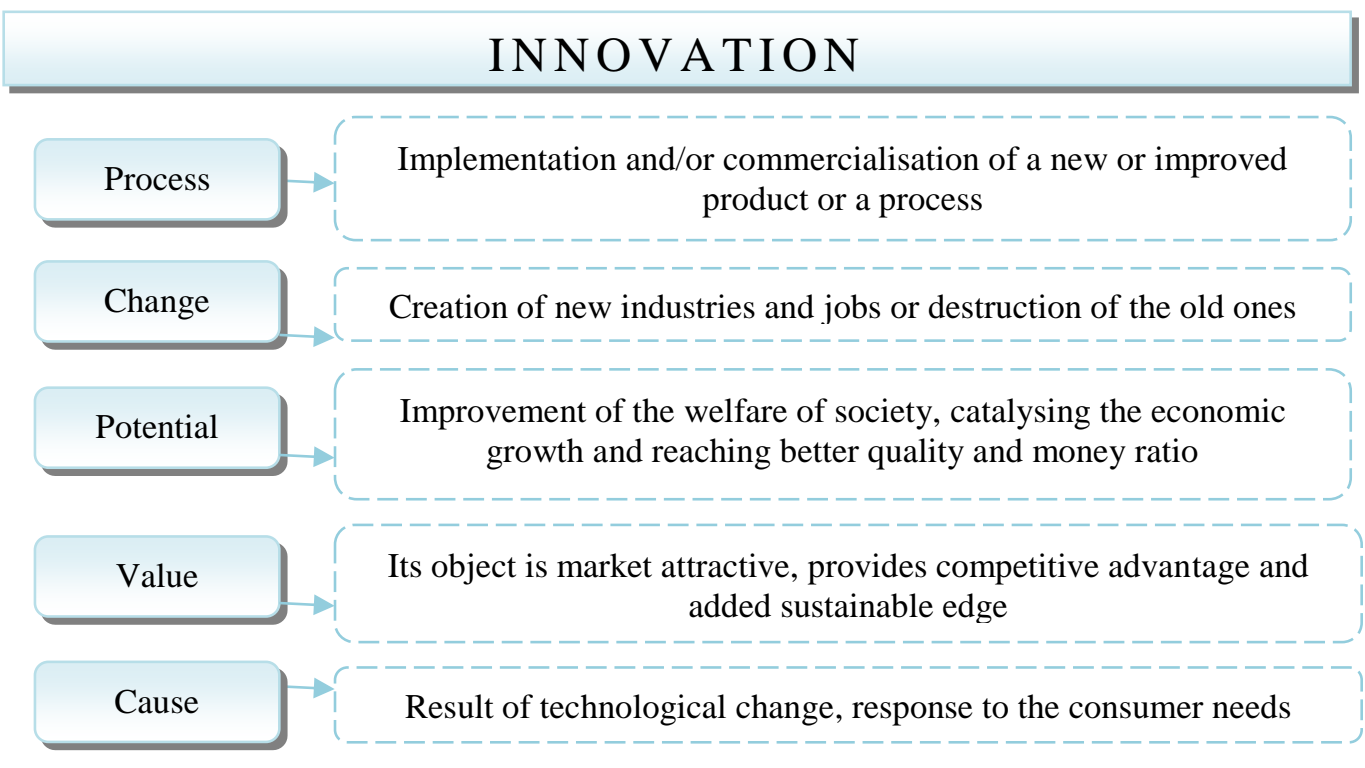

Fig. 1. Innovation concept map (created by the authors).

According to Schumpeter, the innovation process consists of three phases: invention, when a new idea that is favourable to a market is created (Dahlinm, 2005), innovation, when the idea is being implemented into marketable products, and diffusion phase, when the product is being spread to a market. Innovation is the first commercial application phase of the invention.

Since not all innovations are the same, they are classified as typologies to identify their innovative degree (Garcia, 2002) by comparing changes in the underlying concepts to their linkage to components. Open innovations are an inception for knowledge integration (Chesbrough, 2003), evolving cooperation and openness of intellectual property, extermination of single scope skills.

Technology transfer is the process of transferring skills, knowledge and technology from one research organisation to another with the aim of making science and technology progress more accessible to a wider range of users (Mitasiunas, 2013). It has been defined that the key elements of innovative activity interact with each other (Fig.2); however, innovation is the result that benefits society. 


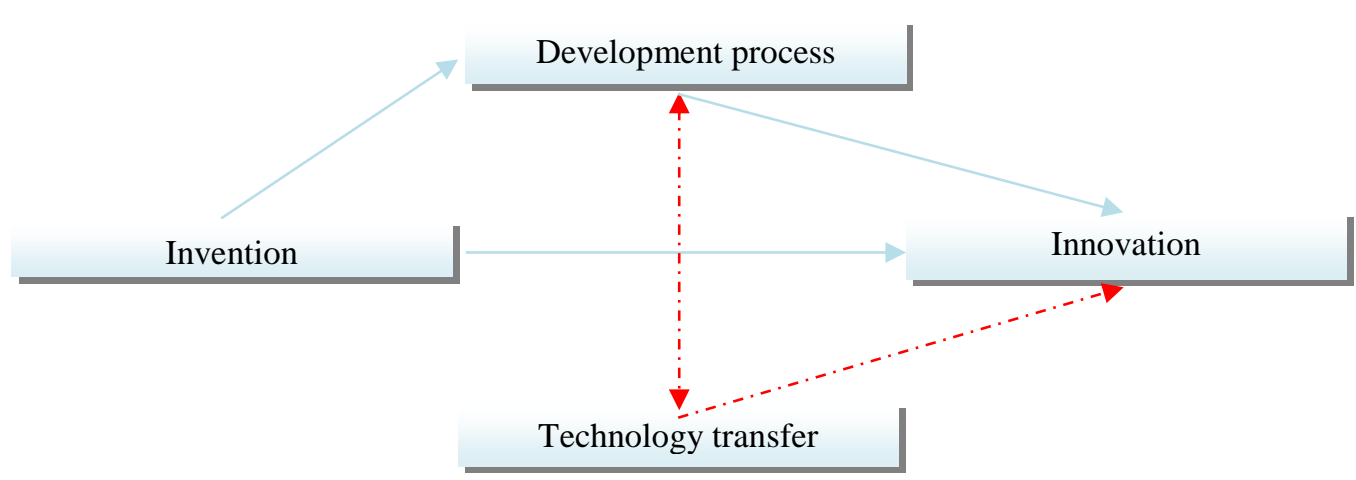

Fig. 2. Elements of innovation (created by the authors).

\subsection{Public Procurement for Innovation: Benefits and Barriers}

Public procurement of innovation and definition of innovation have their discrepancies. The concept of public procurement of innovation is understood as the procurement activity of a public authority leading to innovation. A public body purchases or orders a product, which may be new to the market or not yet available, but which may be developed within a reasonable period (Rolfstam, 2012). The procurement of innovation also involves purchase of products that require research and experimental development.

Although public procurement has a long history, there are challenges to surmount before conducting a successful procedure. Those mainly concern nonexclusion of innovation and process of selecting the award tender:

Specifications for order preparation: the technical specifications developed in a descriptive and detailed manner often reflect current market opportunities and facilitate the purchase of the market products.

The award criteria: in 2017 among EU countries $60 \%$ (European Commission, 2018) of procurement procedures were assessed using the lowest price criterion, which excludes both innovation and healthy competition among suppliers.

Habits: economy reacts slowly to changes and innovations, mostly due to past investment decisions, existing economic structures and dominant institutions. Technological habits (UN, 2014), behavioural patterns (EC, 2011), business models (Hudson, 2013) and institutional norms interfere the innovation process. People have a habit of evaluating an existing one more than before its appearance (Kahneman and Knetsch, 1990). Short-term financial benefits hinder investment in the long term (EC, 2011). When external conditions change, political reforms are lagging behind, leading to situations in which the transition to innovation is delayed (Georghiou, 2014).

Innovation non-encouraging directives: the need to adapt informal collaboration between the customer and the supplier, which may involve technical changes, has never been met by legislation (Rolfstam, 2009). 


\section{RESEARCH PART}

\subsection{The Value of Innovation in Public Procurement}

Concluding that the integrated criteria for assessing innovation procurement have not been developed in Europe, which hinders the implementation of procurement, this paper studies methods for evaluating innovation and selecting the best alternative, so that not only the price criteria are used.

Object evaluation is its compliance with certain norms, needs, and determination of the value offered; the process of determining its quality, significance and/or value (Cambridge, 2018). Hence, in order to evaluate the proposal of innovation in public procurement it is necessary to find out its value.

To define the value for the consumer, Osterwalder (2014) offered using the value map. Value map indicates consumer needs, long-term goals and problems, according to the author's definition, "pains". The closer the proposal is to the customer's profile, the more valuable it is.

\subsection{Practice Analysis: Bid Evaluation Criteria}

In 2014, with the new Public Procurement Directive the EU Commission introduced a new and only award criterion - MEAT (most economically advantageous tender) (European Parliament, 2014). Each contractor is entitled to define the explanatory criteria that are individually considered the best. MEAT includes three indicators: best price-quality ratio (BPQR), which is assessed based on price and cost elements and qualitative criterion, including environmental and social aspects, cost-effectiveness approach, and life-cycle costs (LFC).

The Directive mentions a non-exhaustive list of possible award criteria, including environmental and social aspects, quality, accessibility, technical advantages, aesthetic and functional characteristics, organisational structure, qualifications and experience of performing personnel, but does not determine what weight should be determined for them. However, this paper states that criteria relating to the applicant's profile should be distinguished from the criteria by which a tender is being assessed and the supplier's experience cannot influence the selection, especially if an innovative solution is considered.

The EU Commission does not define the joint quality criterion of the tender and the comprehensive bid evaluation methods. Therefore, the present study examined literature to determine evaluation indicators that could be used to define MEAT:

Quality: according to Cooper et al. (1987), quality is a unique advantage, strong technological, management and marketing synergy. The criterion indicators include customer satisfaction, reliability, and product performance (Story, 1999). Harris (2004) determines the convenience and functionality of a product. Cummings defines quality as the product's ability to meet consumer needs (Cumming, 1998). Cottam (2001) sees innovation as a way to create long-term stability, achieve shareholder returns, maximise employee satisfaction and provides the ability to stay at the forefront of the industry, which contributes to sustainable and balanced 
development. Product quality can be assessed by its market competitiveness and durability (Bossel, 1999).

Financial criteria: cost-effectiveness can be described as "3E" - economy, efficiency, effectiveness: cost reduction, profitability and productivity (Silva, 2016).

Risks: Jasinki (2006) deems that the value of innovation or technology transfer should be determined by their viability, benefits, costs and associated risks.

Degree of novelty: measure of change caused by innovation; it is important to identify it, which would designate potential risks and ways to prevent them before they appear (Garcia \& Calantone, 2002).

Effectiveness: it is determined by the simplicity of the process (Chatzoglou \& Chatzoudes, 2018).

Competitive advantage: innovations manage new knowledge and intellectual capital, increase organisational capacity and enrich its culture. Drucker (1985) emphasises that innovative institutions are more flexible and better adapt to changes.

Table 1 summarises the criteria groups and their indicators that can be used to define MEAT in public procurement of innovations.

Table 1. Criteria and their Indicators for Evaluation of Innovation Proposals (created by the authors)

\begin{tabular}{|l|l|}
\hline \multicolumn{1}{|c|}{ Criteria } & \multicolumn{1}{c|}{ Indicator } \\
\hline Quality & $\begin{array}{l}\text { Future product lifetime (Astebro, 2005); Sustainability (Griffin, 1993; } \\
\text { Sawang, 2011; De Felice, 2013; Edison, 2013); Performance of innovation } \\
\text { (Kobayashi, 2006; Van Hoof, 2014); Durability (Alcaide-Marzal, 2007); } \\
\text { Eco-effectiveness of a product, ecodesign (EC, 2010; Mendes, 2015); } \\
\text { Marketability (EC, 2010); Performance; Ease of usability (Mendes, 2015) }\end{array}$ \\
\hline Time to market (Tipping, 1995) \\
\hline $\begin{array}{l}\text { Financial } \\
\text { performance }\end{array}$ & $\begin{array}{l}\text { Life cycle cost, efficiency, profitability, payback period (Rochford, } \\
1991)^{57} ; \text { Availability of funds (Hittmar, 2015) }\end{array}$ \\
\hline $\begin{array}{l}\text { Supplier's } \\
\text { competences }\end{array}$ & Availability of resources \\
\hline Risks & $\begin{array}{l}\text { Organisational and societal risks, market risks, technological risks, } \\
\text { financial risks, political or economic risks (EC, 2010) } 39\end{array}$ \\
\hline Perceived value & Window on new market 44 \\
\hline Logistics & Supply chain (Mendes, 2015) \\
\hline $\begin{array}{l}\text { Environmental } \\
\text { impact }\end{array}$ & $\begin{array}{l}\text { Amount of energy consumed, transport emissions, energy efficiency, } \\
\text { emissions, fuel consumption }\end{array}$ \\
\hline Functionality & $\begin{array}{l}\text { Comparative functionality (Astebro, 2005); Solution oriented functionality } \\
\text { (Fern, 2014) }\end{array}$ \\
\hline $\begin{array}{l}\text { Management } \\
\text { structure }\end{array}$ & $\begin{array}{l}\text { Implemented quality management (ISO or similar), experience and } \\
\text { education of responsible personnel, financial stability }\end{array}$ \\
\hline Social criteria & $\begin{array}{l}\text { Employment of persons with special needs, at pre-retirement age and } \\
\text { persons under probation, number of persons who may have an internship } \\
\text { within the number of new job positions created }\end{array}$ \\
\hline $\begin{array}{l}\text { Dechnology transfer, innovation, unique benefits (Brentani, 2001) } \\
\text { innovativeness }\end{array}$ & $\begin{array}{l}\text { International competitive advantage (Cooper, 1987); National competitive } \\
\text { advantage (Chatzoglou, 2018) }\end{array}$ \\
\hline $\begin{array}{l}\text { Competitive } \\
\text { advantage }\end{array}$ & Effectiveness \\
\hline
\end{tabular}




\subsection{Research: Expert Method}

Evaluating a product before its commercialisation is difficult and tends to be biased, as it is largely based on expert opinions and experience that are dependent on the current market situation, potential and capabilities, which tend to make creative thinking difficult.

In order to determine the most appropriate criteria for the evaluation of innovation proposals from those that were compiled after the analysis of the literature and to determine their degree of importance in different economy sectors, the study was based on the expert method.

The research period lasted from February to December 2018. Forty-nine experts from twenty-one economy sectors participated in the study; experts were invited to assess the evaluation criteria. The experience of each expert is longer than three years in their field; experts included managers of private companies, professors, leading specialists of ministries of the Republic of Latvia and other state institutions.

First, experts discussed the possible types of innovation in an industry, then clarified concept and the role the public procurement of innovations, as well as its limitations and challenges. Experts were asked to evaluate 14 criteria (Table 1) of innovation and relevance of their indicators. Importance of criteria was identified by comparing each of the two criteria to the potential for innovation success. More conducive conditions to enhancing innovation value were also determined.

No complete consensus was established due to industry differentials. After the first interviews, the inadequacy of the two criteria "supplier's competences" and "management structure" was concluded and they were not discussed further in the interviews.

\subsection{The Analytic Hierarchy Process}

The Analytic Hierarchy Process was used to analyse the responses. Experts compared the criteria according to a 7-point scale, where 1 is the equality of criteria, while 7 determines the very importance of one criterion. For each group of criteria, a normalised priority vector was determined (Saaty, 1987).

Thomas Saaty, the author of the HAM method, determines the consistency of the matrix (Consistency Ratio) by no more than $10 \%$, but for large matrices, as well as when the valuation object is not clearly defined (potential innovation), a consistency ratio of up to $20 \%$ is acceptable (Saaty, 2012). Analysis of the matrices completed by the experts was calculated by relative weight of each criterion in different sectors and in general.

Overall, the group of quality indicators reached the highest weight with $16.6 \%$, followed by functionality $(10.6 \%)$ and environmental impact criteria $(10.1 \%)$ (Fig. 3). Such a ratio is considered logical as functionality is closely related to quality and innovation must be environmentally friendly. 


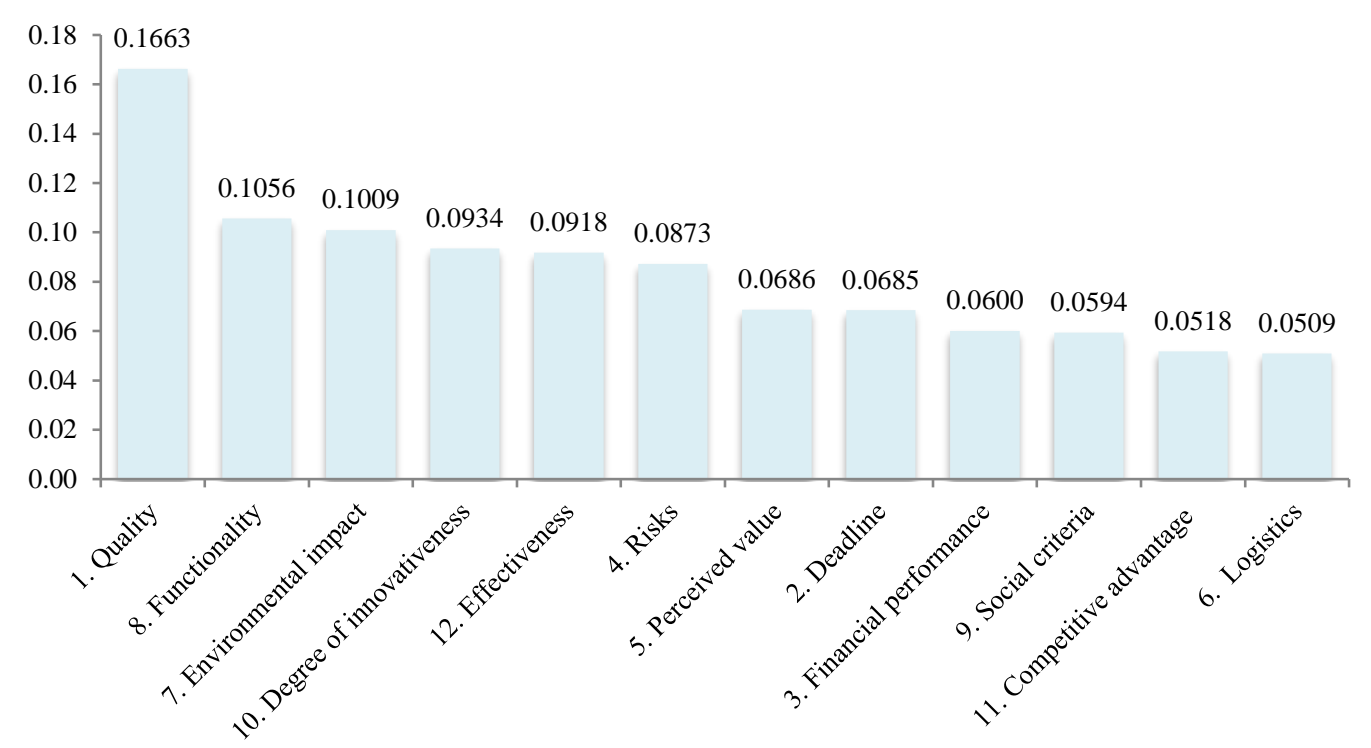

Fig. 3. Innovation evaluation criteria weight (created by the authors).

After assessment the criteria and their indicators, to simplify the evaluation of offers, it was decided to group some criteria into four groups. The groups were formed based on their expert mark and reciprocal link. The weight of the significance of criteria and sub-criteria groups was determined by the AHP results.

\section{GUIDELINES FOR THE BEST ALTERNATIVE SELECTION}

The customer defines what quality criteria will be assessed, what methodology will be used and how the overall quality score will be obtained from different variables. The aim of the best alternative selection is to determine which offer best meets the requirements of a request for proposal or which one will provide the customer with the greatest value. The criteria for evaluating innovation offers should reflect the customer's sustainable, smart and socially oriented goals.

The criteria, which will be used to evaluate innovation, should be interpreted by means of indicators. Following the assessment guidelines, the buyer can define the similarities and differences between competing bids, as well as the strengths and weaknesses, and justly select the best alternative.

To prevent inexpedient use of public funds in public procurement for innovation, the study suggests using the agile methodology (Highsmith, 2009). When examining public procurement as a project, the agile methodology makes it possible to implement the procurement procedure faster and easier - avoiding difficult corrections and rare communication with suppliers and saving money.

\subsection{Innovation Proposal Evaluation}

Depending on the sector and target product of the innovation, the order of the evaluation stages can be changed; some may be omitted or divided into smaller levels (Fig. 4). 
Beginning of the proposal evaluation process

Step 1: Proposal compliance with minimum requirements

Step 2: Evaluation of the proposal quality

Step 3: Determination of the added value of the proposal

Step 4: Identification of the risks of the proposal, the cost analysis and evaluation of other non-financial factors

Step 5: Identification of the social benefits of the proposal

Selection of the best alternative

Fig. 4. Framework for the evaluation of innovation proposals (created by the authors).

\section{Step 1: Compulsory Requirements}

At this stage, the bidding commission should assess the compliance of the bid with the minimum requirements, if any, mentioned in the RFP. Mandatory conditions may be related to the maximum budget and the duration of the deadlines, or other factors that are relevant to the customer.

Step 2: Evaluation of the Tender Quality

The quality criterion group applies to sustainability (indicators: ecology, society, economy), functionality (indicators: efficiency, effectiveness, technical advantage), environmental impact (indicators: eco-design, resource consumption, emission), and proposal performance (indicators: design, usability). Starting from Step 2, the buyer determines weight of each subsequent step before the procurement publication.

\section{Step 3: Determination of the Added Value of the Proposal}

The value of innovation is reflected in the improvements provided. To evaluate the proposals at this stage, it is necessary to determine the level of innovation, the competitive advantage and the added value provided to the customer.

Step 3.1: Innovation Measurement

What gets measured gets done (Drucker, 1954). It is important to determine what changes the submitted proposal can cause, what and how much investment is needed in resources and how valuable they can be. This stage is important for assessing the ability of innovation to influence and promote smart development.

The basis of the valuation approach was the Porter's value chain (Porter, 1985), which reflected the organisation's primary and supporting activities. A new product 
is expected to affect the value chain activities by requiring re-organisation of the current processes.

Step 4: Identification of the Risks of the Proposal, the Cost Analysis and Evaluation of Other Non-financial Factors

At the risk assessment stage, attention is devoted to the weakness of the supply of innovation to be affected by a particular risk and the ability to avoid it. In the cost analysis, only the costs of the public customer are calculated in the guidelines. Non-financial factors include the due date of the performance and logistics.

A complete understanding of all the costs that make up the total cost of the system over its lifetime will allow for a significant reduction in energy, operating and maintenance costs, with significant environmental benefits (Woodward, 1997).

Step 5: Social Criteria

In order to make the selection of alternatives in public procurement as objective and comprehensive as possible, it is necessary to calculate their impact on society. Social innovations are new ideas that meet social needs, build social relationships and new collaborations.

\subsection{Selecting the Best Alternative}

Once the bids have been evaluated at all stages, it is possible to define which one offers the greatest value and is the most economically advantageous. When evaluating the sustainability of a product, it is necessary to distinguish separate processes: product evaluation, analysis of the manufacturing process, as well as the evaluation of the production equipment. Evaluating consumer goals differs if the public procurer has an investor role. Before evaluating a tender, it is crucial to determine its consumer, a final user or an innovation buyer.

\section{CONCLUSION}

In the light of the increasing concern for public procurement for innovation, this paper has aimed at providing better knowledge on how public bodies can evaluate the received proposals. It has been concluded that public organisations lack the knowledge of public procurement for innovation opportunities and its implementation procedure. Theoretically, the paper contributes to the development of smart PPI platform for tender evaluation. Innovation mandatory features create a new value and deliver benefits to the user. Its evaluation is based on the analysis of the value it offers, the impact potential and the sustainability of the changes caused. The functional description of the required object creates significant obstacles to the development of the procurement and objective evaluation of tenders; therefore, it is necessary to involve industry experts in public procurement, who can assist the procurer to develop the right procurement description.

The price and cost of an innovation offer does not reflect its added value. When implementing innovation procurement, it is necessary to evaluate the offers according to qualitative criteria, which reflect its impact, the degree of novelty and the level of profitability. In the process of developing the guidelines for public procurement of innovation evaluation, the issue has been raised whether it is 
necessary to complicate the evaluation process with quantitative indicators. An outcome of each change can be reflected in financial terms, but it is a timeconsuming and resource-intensive process. This issue is the basis for the authors' further research.

\section{REFERENCES}

Abou-Zeid, E. (2004). The effectiveness of innovation: a knowledge management approach. International Journal of Innovation Management, 8(3), 261-274. https://doi.org/10.1142/S1363919604001052

Ahuja, G. \& Lampert, C. M. (2001). Entrepreneurship in large corporations: a longitudinal study of how established firms create breakthrough inventions. Strategic Management Journal, 22(6-7), 521-543. https://doi.org/10.1002/smj.176

Alcaide-Marzal, J. \& Tortajada-Esparza, E. (2007). Innovation assessment in traditional industries. A proposal of aesthetic innovation indicators, Scientometrics, 72(1), 33-57. https://doi.org/10.1007/s11192-007-1708-x

Astebro, T. \& Michela, J. L. (2005). Predictors of the survival of innovations. Journal of Product Innovation Management, 22(4), 322-335. https://doi.org/10.1111/j.0737-6782.2005.00129.x

Bossel, H. (1999). Indicators for sustainable development: theory, method, applications; a report to the Balaton Group. International Institute for Sustainable Development, 1-12.

Brentani, U. (2001). Innovative versus incremental new business services: Different keys for achieving success. Journal of Product Innovation Management, 18(3), 169-187. https://doi.org/10.1111/1540-5885.1830169

Cambridge Dictionary. (2018). Evaluation definition. Retrieved from https://dictionary.cambridge.org/dictionary/english/evaluation

Chatzoglou, P. \& Chatzoudes, D. (2018). The role of innovation in building competitive advantages: an empirical investigation. European Journal of Innovation Management, 21(1), 44-69. https://doi.org/10.1108/EJIM-02-2017-0015

Chesbrough, H. (2003). Open Innovation: The New Imperative for Creating and Profiting from Technology. Boston: Harvard Business School Press.

Cooper, R. G. \& Kleinschmidt, E. J. (1987). Success factors in product innovation, Industrial Marketing Management, 16(3), 215-223. https://doi.org/10.1016/0019-8501(87)90029-0

Cottam, A., Ensor, J., \& Band, C. (2001). A benchmark study of strategic commitment to innovation. European Journal of Innovation Management, 4(2), 88-94. https://doi.org/10.1108/14601060110390594

Cox, A. \& Furlong, P. (1995). Utilities contracting and the EU procurement rules: National contract awards behaviour under the EU directives. Utilities Policy, 5(3-4), 199-206. https://doi.org/10.1016/0957-1787(96)00003-3

Cumming, B. S. (1998). Innovation overview and future challenges. European Journal of Innovation Management, 1(1), 21-29. https://doi.org/10.1108/14601069810368485

De Felice, F., \& Petrillo, A. (2013). Key success factors for organizational innovation in the fashion industry. International Journal of Engineering Business Management, 5, 1-11. https://doi.org/10.5772/56882

Drucker, P. F. (1954). The Practice of Management. UK: Harper Business.

Drucker, P. F. (1985). The discipline of innovation. Harvard Business Review, 63, 67-72.

Edison, H., bin Ali, N., \& Torkar, R. (2013). Towards innovation measurement in the software industry. Journal of Systems and Software 86(5), 1390-1407. https://doi.org/10.1016/j.jss.2013.01.013

European commission. (2018). Procurement Scoreboard. Retrieved from http://ec.europa.eu/internal_market/scoreboard/performance_per_policy_area/public_procurem ent/index_en.htm

European commission. (2019). Procurement factsheet. Retrieved from https://www.europarl.europa.eu/factsheets/en/sheet/34/public-procurement-contracts 
European Parliament. (2014). Directive 2014/24/EU on public procurement. Retrieved from http://data.europa.eu/eli/di r/2014 /24/2018-01-01

Fern, W. (2014). Quality criteria and indicators for responsible research and innovation: learning from transdisciplinarity, Journal of Responsible Innovation, 1, 254-273. https://doi.org/10.1080/23299460.2014.963004

Garcia, R. \& Calantone, R. (2002). A critical look at technological innovation typology and innovativeness terminology: a literature review. The journal of Product innovation management, 19(2), 110-132. https://doi.org/10.1111/1540-5885.1920110

Georghiou, L. et al. (2014). Policy instruments for public procurement of innovation: Choice, design and assessment. Technological Forecasting and Social Change, 86, 1-12. https://doi.org/10.1016/j.techfore.2013.09.018

Griffin, A. \& Page, A. L. (1993). An interim report on measuring product development success and failure. Journal of Product Innovation Management, 10(4), 291-308. https://doi.org/10.1016/0737-6782(93)90072-X

Hamberg, D. (1959). Production Functions, Innovations, and Economic Growth. Journal of Political Economy, 67, 238-245. https://doi.org/10.1086/258173

Harris, D. \& Harris, F. (2004). Evaluating the Transfer of Technology between Application Domains: A Critical Evaluation of the Human Component in the System. Technology in Society, 26(4), 551-565. https://doi.org/10.1016/j.techsoc.2004.08.003

Hennicke, P. \& Khosta, A. (2014). Decoupling Economic growth from resource consumption. Berlin: Deutsche Gesellschaft für Internationale Zusammenarbeit (GIZ) GmbH.

Highsmith, J. (2009). Agile Project Management, $2^{\text {nd }}$ ed. UK: Addison-Wesley Professional.

Hittmar, S., Varmus, M. \& Lendel, V. (2015). Proposal of Evaluation System for Successful Application of Innovation Strategy through a Set of Indicators. Procedia Economics and Finance, 26, 17-22. https://doi.org/10.1016/S2212-5671(15)00796-0

Hudson, J. \& Kühner, S. (2013). Qualitative Comparative Analysis And Applied Public Policy Analysis: New Applications Of Innovative Methods. Policy And Society, 32(4), 279-287. https://doi.org/10.1016/j.polsoc.2013.10.001

Jasinki, A. H. (2006). Barriers for technology transfer: the case of a country in transition. Journal of Technology Management in China, 4(2), 119-131. https://doi.org/10.1108/17468770910964984

Kahneman , D., Knetsch, J. \& Thaler, R. H. (1990). Experimental Tests Of The Endowment Effect And The Coase Theorem. Journal Of Political Economy, 98, 325-348. https://doi.org/10.1086/261737

Kobayashi, H. (2006). A systematic approach to eco-innovative product design based on life cycle planning. Advanced Engineering Informatics, 20(2), 113-125. https://doi.org/10.1016/j.aei.2005.11.002

Kunzlik, P. (2013). Neoliberalism and the European Public Procurement Regime. Cambridge Yearbook of European Legal Studies, $\quad 15, \quad 283-356$. https://doi.org/10.5235/152888713809813666

Lember, V., Kattel, R. \& Kalvet, T. eds. (2014). Public Procurement, Innovation and Policy. International perspectives. Springer Nature Switzerland AG. https://doi.org/10.1007/978-3-64240258-6

Luz, L. M., de Francisco, A. C., \& Piekarski, C. M. (2015). Proposed model for assessing the contribution of the indicators obtained from the analysis of life-cycle inventory to the generation of industry innovation. Journal of Cleaner Production, 96, 339-348. https://doi.org/10.1016/j.jclepro.2014.03.004

Mitasiunas, J. (2013). Innovation and Technology Transfer Jonas. Retrieved from www.bonitaproject.eu/cms_uploads/files/a02innovationtech.pdf

Osterwalder, A. (2014). Value Proposition Design. Retrieved from noahc.me/Value\%20Proposition\%20Design.pdf

Porter, M. E. (1985). Competitive Advantage: Creating and Sustaining Superior Performance. NY: The Free Pres. 557 p.

Rochford, L. (1991). Generating and screening new products ideas. Industrial Marketing Management, 20(4), 287-296. https://doi.org/10.1016/0019-8501(91)90003-X 
Rolfstam, M. (2009). Public procurement as an innovation policy tool: the role of institutions. Science and Public Policy, 36(5), 349-360. https://doi.org/10.3152/030234209X442025

Rolfstam, M. (2012). Understanding Public Procurement of Innovation: Definitions, Innovation Types and Interaction Modes. SSRN Electronic Journal, 1-16. https://doi.org/10.2139/ssrn.2011488

Saaty, R. W. (1987). The analytic hierarchy process - what it is and how it is used. Mathematical Modelling, 9(3-5), 161-176. https://doi.org/10.1016/0270-0255(87)90473-8

Saaty, T. \& Vargas, L. G. (2012). Models, Methods, Concepts \& Applications of the Analytic Hierarchy Process. Operations Research \& Management Science book series, 175, 13-54. https://doi.org/10.1007/978-1-4614-3597-6

Sawang, Sukanlaya. (2011). Key performance indicators for innovation implementation: Perception vs. actual usage. Asia Pacific Management Review, 16, 23-29.

Schumpeter, J. (1942). Capitalism, Socialism, and Democracy. USA: Harper \& Brothers.

Schumpeter, J. (1983). The theory of Economic Development. New Jersey: Transaction Publishers.

Silva, G. \& Di Serio, L. C. (2016). The sixth wave of innovation: are we ready? RAI Revista de Administração e Inovação, 13(2), 128-134. https://doi.org/10.1016/j.rai.2016.03.005

Stark, J. (2011). Product Lifecycle Management, $2^{\text {nd }}$ ed. Springer.

Story, V., Smith, G. \& Saker, J. (2001). Developing Appropriate Measures of Success and Failure in New Product Development: A Contingency Approach. International Journal of Innovation Management, 5(1), 21-47. https://doi.org/10.1142/S1363919601000282

Tipping, P. (1995). Foaming in Activated-Sludge Processes: An Operator's Overview. Water and Environment Journal, 9(3), 281-289. https://doi.org/10.1111/j.1747-6593.1995.tb00941.x

Ultrich, K. (2008). Product design and development. UK: McGraw-Hil International Edition.

United Nations Environment Programme. (2014). Decoupling 2 Technologies, Opportunities and Policy Options. Retrieved from http://wedocs.unep.org/handle/20.500.11822/8892

Van Hoof, G. et. al. (2014). Assessment of progressive product innovation on key environmental indicators: Pampers ${ }^{\circledR}$ Baby Wipes from 2007-2013. Sustainability, 6(8), 5129-5142. https://doi.org/10.3390/su6085129

Wickson, F., \& Carew, A. (2014). Quality criteria and indicators for responsible research and innovation: learning from transdisciplinarity. Journal of Responsible Innovation, 1(3), 254-273. https://doi.org/10.1080/23299460.2014.963004

Woodward, D. (1997). Life Cycle Costing - Theory, Information Acquisition and Application. International Journal of Project Management, 15(6), 335-344. https://doi.org/10.1016/S02637863(96)00089-0

\section{AUTHORS' SHORT BIOGRAPHIES}

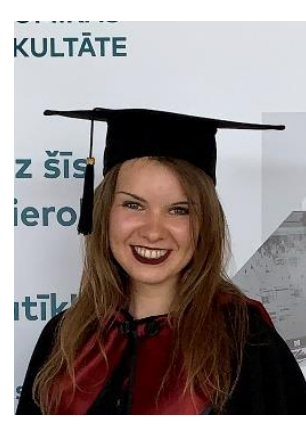

innovation.
Viktorija Babica is a first-year $\mathrm{PhD}$ student of the study programme "Management Science and Economics" at Riga Technical University, a Junior Accountant at Bureau Veritas Latvia, LTD, and a founder of children's entertainment company ConTigo, LTD. Viktorija delivers classes in E-commerce, conducts research on business process digitalisation and runs her own company, which organises international summer camps for youth. Viktorija has presented her research results at student scientific conferences as well as at RTU Annual Scientific Conference and AIBCEE'2019 in Kaunas, Lithuania. Viktorija attended Future Leaders Academy 2018 organised by Stockholm School of Economics in Riga. Viktorija's main study field is digitalisation, entrepreneurship and

E-mail: Viktorija.babica@rtu.lv 


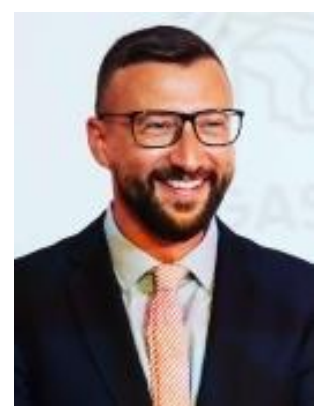

Dr. Deniss Ščeulovs is an Associate Professor of the Faculty of Engineering Economics and Management at Riga Technical University (Latvia). He is the author and co-author of more than fifty articles published in scientific journals indexed and abstracted in SCOPUS, Web of Science and other international databases. Dr. Ščeulovs has participated in more than thirty international scientific conferences organised in the USA, Canada, Hong Kong, the Czech Republic, Georgia, Malta, Latvia etc. He is actively involved in the EU funded and other international scientific projects as the leader and researcher. Dr. Ščeulovs has developed versatile entrepreneurial skills working in top management positions at the Latvian manufacturing company Latsign Ltd. and consulting business companies over the past ten years. His research interests lie in the area of digital economy, entrepreneurship, marketing and small business organisation.

E-mail: Deniss.Sceulovs@ rtu.lv

ORCID iD: https://orcid.org/0000-0002-1570-0072 